\title{
Effect of Dietary Mineral Sources and Oil Content on Calcium Utilization and Kidney Calcification in Female Fischer Rats Fed Low-Protein Diets
}

\author{
Shizuko OHTSUKA ${ }^{1}$, Yoshiko AOYAMA ${ }^{2}$, Nobuhiro WATANABE ${ }^{2}$, Tomoko KAJIWARA ${ }^{2}$, \\ Shoji AZAMI ${ }^{1}$ and Takao KITANO ${ }^{3}$ \\ ${ }^{1}$ Department of Administrative Nutrition, Faculty of Health and Nutrition, Tokyo Seiei College, \\ 4-6 Nishishinkoiwa 1-chome, Katsushika-ku, Tokyo 124-8530, Japan \\ ${ }^{2}$ Material Research Center Co., Ltd., 3-25-13-4F Tonomachi, Kawasaki-ku, Kawasaki 210-0821, Japan \\ ${ }^{3}$ Department of Public Health, Graduate School of Life Sciences, Kumamoto University, 1-1-1 Honjo, \\ Chuo-ku, Kumamoto 860-8556, Japan
}

(Received July 5, 2012)

\begin{abstract}
Summary We studied the effects of dietary mineral source and oil intake on kidney calcification in 4-wk-old female Fischer rats after consuming the AIN-76 purified diet (AIN-76). A modified AIN-76 mineral mixture was used, although the original calcium (Ca)/phosphorus $(\mathrm{P})$ molar ratio remained unchanged. Rats were fed the modified diets for a period of $40 \mathrm{~d}$ before their kidneys were removed on the last day. Ca balance tests were performed on days 31 to 36 and biochemical analysis of urine was also studied. Kidney Ca, P, and magnesium $(\mathrm{Mg})$ in the standard diet group (20\% protein and 5\% oil) were not affected by the mineral source. Kidney Ca, P, and Mg in the low-protein (10\% protein) diet group, were found to be influenced by the dietary oil content and mineral source. In particular, the different mineral sources differentially increased kidney mineral accumulation. Pathological examination of the kidney showed that the degree of kidney calcification was proportional to the dietary oil content in the $10 \%$ dietary protein group, reflecting the calcium content of the kidney. The information gathered on mineral sources in this study will help future researchers studying the influence of dietary $\mathrm{Ca} / \mathrm{P}$ molar ratios, and histological changes in the kidney.
\end{abstract}

Key Words mineral source, protein intake, oil intake, AIN-76 purified diets, kidney calcification

Our research has focused on the effect of the quality and quantity of protein intake on calcium (Ca) utilization and kidney calcification in rats (1-4). We have shown that an increase in the intake of casein or soybean protein increases urinary $\mathrm{Ca}$ excretion without affecting Ca absorption or retention. The kidney Ca content was reduced by an increase in protein intake.

We also reported that a simultaneous increase in oil intake and alteration in protein intake markedly increased the kidney Ca content, especially in rats fed a low-protein, high-oil diet (5).

Animal experiments were conducted using appropriately modified diets, based on the American Institute of Nutrition (AIN) purified diet 76 (AIN-76) (6).

AIN-76 has been used worldwide in many animal experiments since 1977, when the AIN approved it as a standard diet. In 1993, AIN-76 was improved to produce the AIN-93 purified diet (7), partially because AIN76 caused kidney calcification when used in female rats. The AIN implicated the $\mathrm{Ca} /$ phosphorus $(\mathrm{P})$ molar ratio of AIN-76 in kidney calcification.

Several studies have shown that kidney calcification observed in rats fed AIN-76 was provoked not only by inappropriate $\mathrm{Ca} / \mathrm{P}$ molar ratios but also by the intake

E-mail: otsuka@tsc-05.ac.jp of other nutrients $(8-11)$. The results suggested that the causes of kidney calcification after consuming the AIN-76 diet were influenced by nutrients such as protein and oil, in addition to the $\mathrm{Ca} / \mathrm{P}$ molar ratio of the AIN-76 diet. Calcium and phosphorus sources in the mineral mixture of the AIN-76 diet were derived from calcium phosphate $\left(\mathrm{CaHPO}_{4} \cdot 2 \mathrm{H}_{2} \mathrm{O}\right)$ and although we have changed the calcium and phosphorus sources it is still important to consider the mineral content and form of the mineral mixture because these influence mineral metabolism.

We changed the Ca and $\mathrm{P}$ sources to clarify the quantitative and qualitative effects of $\mathrm{Ca}$ and $\mathrm{P}$ on Ca utilization and kidney calcification in rats.

We studied the relationship between Ca utilization and kidney calcification using a modified AIN76 , in which we changed the Ca source from calcium phosphate $\left(\mathrm{CaHPO}_{4} \cdot 2 \mathrm{H}_{2} \mathrm{O}\right)$ to calcium citrate $\left(\mathrm{Ca}_{3}\left(\mathrm{C}_{6} \mathrm{H}_{5} \mathrm{O}_{7}\right)_{2} \cdot 4 \mathrm{H}_{2} \mathrm{O}\right)$ and the $\mathrm{P}$ source from calcium phosphate $\left(\mathrm{CaHPO}_{4} \cdot 2 \mathrm{H}_{2} \mathrm{O}\right)$ to potassium phosphate $\left(\mathrm{KH}_{2} \mathrm{PO}_{4}\right)$, without any change to the $\mathrm{Ca} / \mathrm{P}$ molar ratio, so that alterations to the composition and contents of other minerals were minimized.

In addition, we examined the effects of various amounts of oil intake on kidney calcification in rats fed low-protein diets, as used in our previous studies. 
Table 1. Composition of the experimental diets.

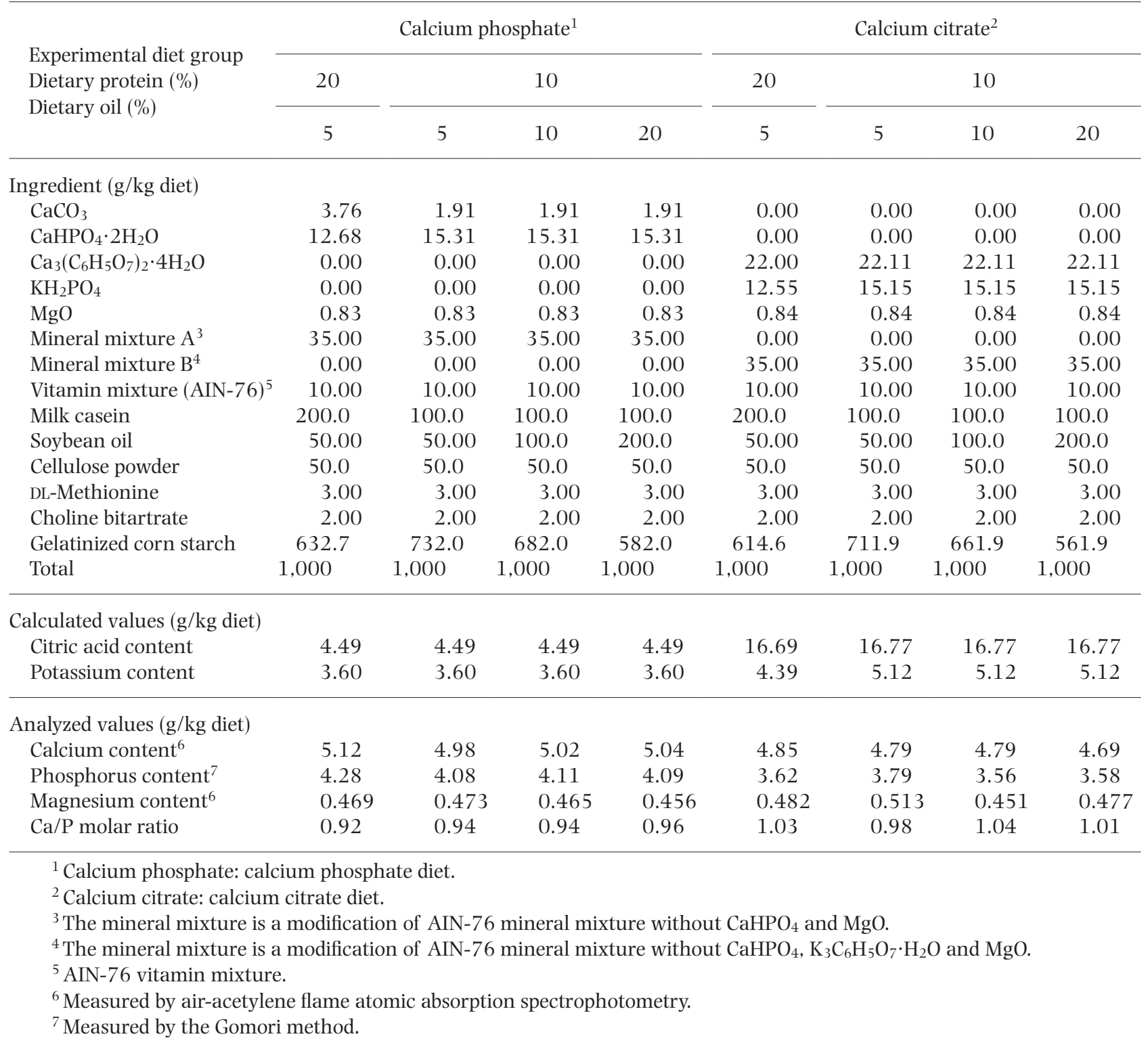

\section{EXPERIMENTAL METHODS}

1. Experimental diet. Table 1 shows the composition of diets prepared by modifying AIN-76. They contained 10 or $20 \%$ protein. The $20 \%$ protein diet group was fed a $5 \%$ oil diet while the $10 \%$ protein diet group was fed a 5,10 , or $20 \%$ oil diet. Diets were supplemented with minerals from phosphates and citrates to prepare 8 kinds of experimental diets.

The calcium phosphate diets (P diets) was unchanged in mineral source. The calcium citrate diets (C diets) was prepared by replacing calcium phosphate $\left(\mathrm{CaHPO}_{4} \cdot 2 \mathrm{H}_{2} \mathrm{O}\right)$ of AIN-76 with calcium citrate $\left(\mathrm{Ca}_{3}\left(\mathrm{C}_{6} \mathrm{H}_{5} \mathrm{O}_{7}\right)_{2} \cdot 4 \mathrm{H}_{2} \mathrm{O}\right)$ as the $\mathrm{Ca}$ source and replacing calcium phosphate $\left(\mathrm{CaHPO}_{4} \cdot 2 \mathrm{H}_{2} \mathrm{O}\right)$ of $\mathrm{AIN}-76$ with potassium phosphate $\left(\mathrm{KH}_{2} \mathrm{PO}_{4}\right)$ as the $\mathrm{P}$ source. Dietary $\mathrm{Ca}$ and $\mathrm{P}$ contents were adjusted after taking the caseinderived $\mathrm{Ca}$ and $\mathrm{P}$ into account. Other components were controlled as reported previously (2).

The potassium content was increased compared to the basic AIN-76; it was not increased to $0.360 \%$ in the $\mathrm{P}$ diets, in which there was no change in Ca source, while the content was increased to $0.512 \%$ and $0.439 \%$ in the $10 \%$ and $20 \%$ protein diets, respectively, in the $\mathrm{C}$ diets. The content of citrate $\left(\mathrm{C}_{6} \mathrm{H}_{5} \mathrm{O}_{7}\right)$ was $0.449 \%$ in both the 10 and $20 \%$ protein diets in the $\mathrm{P}$ diets while it was increased to $1.67 \%$ in both the $\mathrm{C}$ diets.

2. Experimental animals, housing and diets. We used 48 4-wk-old female Fischer 344 rats (CLEA Japan, Inc.). They were housed individually in metabolism cages where a 12-h dark-light cycle (light on, 8:00-20:00 h), room temperature of $24 \pm 1^{\circ} \mathrm{C}$, and humidity of $55 \pm 5 \%$ were maintained. Rats had free access to deionized water and the experimental diet.

After the 5-d pre-experimental period, rats were divided into 8 groups of 6 rats so that the mean body weight of each group was the same and they were kept for a period of $40 \mathrm{~d}$. They were anesthetized with Nembutal after a 16-h fast. Blood samples were then drawn from the abdominal aorta and kidneys were removed. 

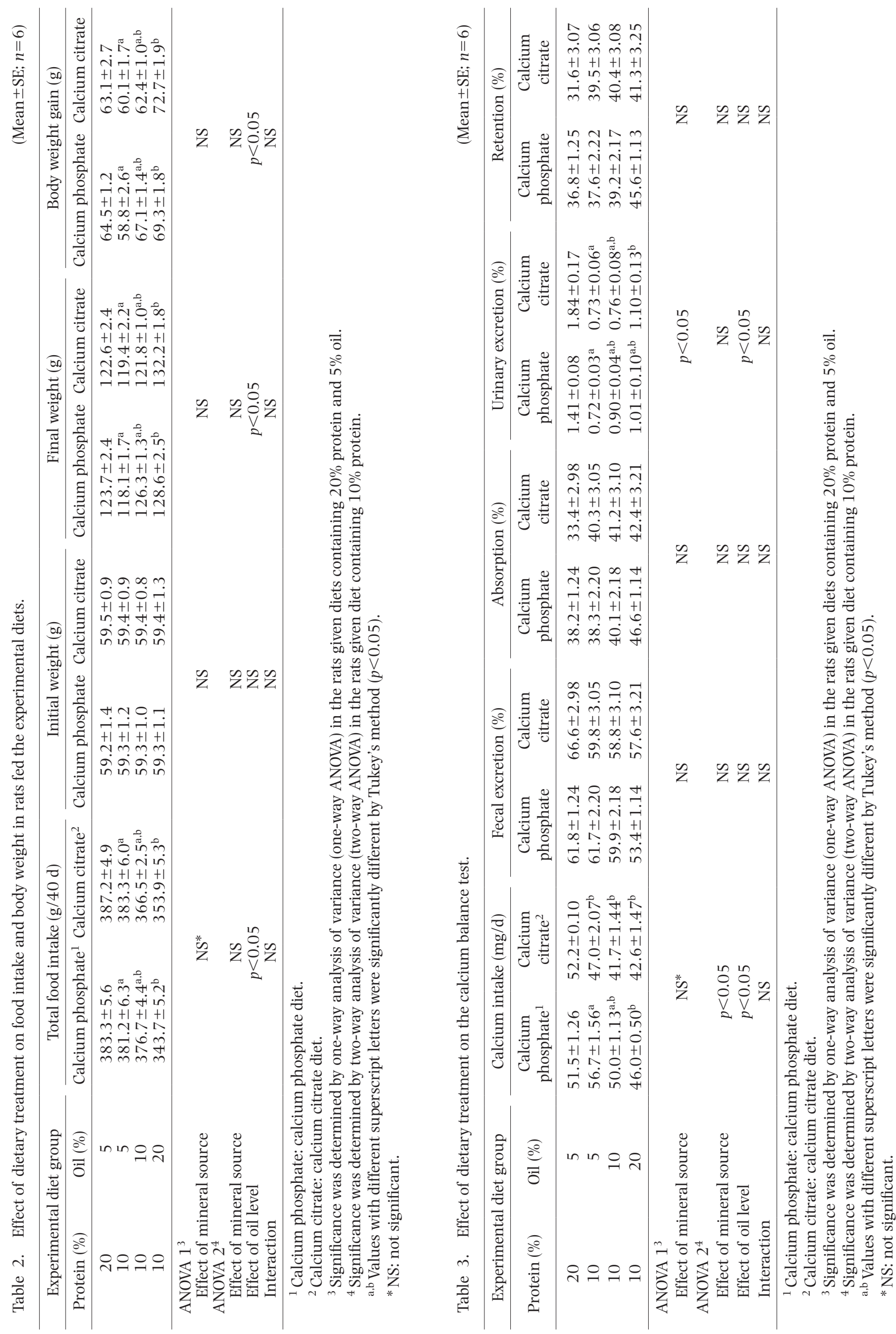


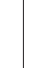

卷

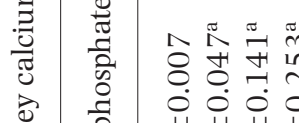

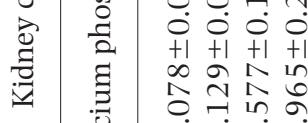

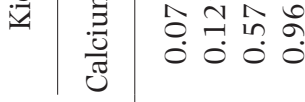

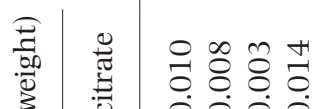

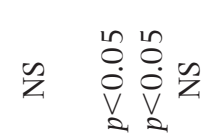

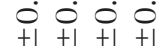

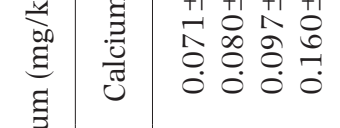

胥

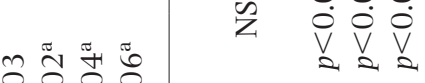

훙

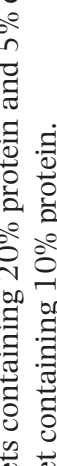

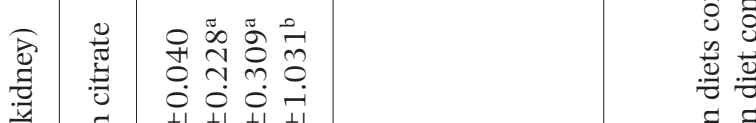

总 突

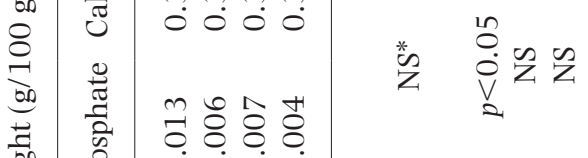

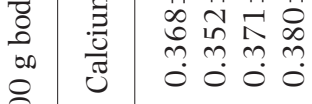

흘

范

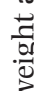

害

品

चี

की

3 aे $+1+1+1+1$

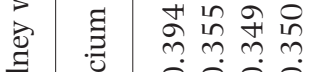

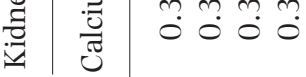

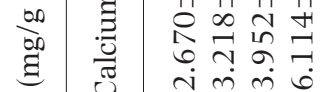

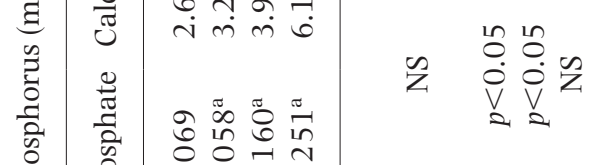

卷芯

诺

$\exists . \Xi$

就

䘮全总

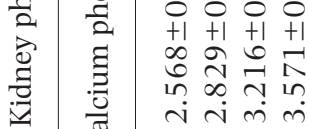

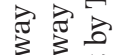

究产苞

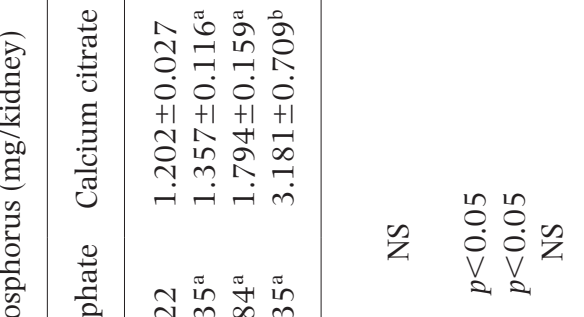

论

芯 范

$\div$ 의

s.

芉 สี ฮี

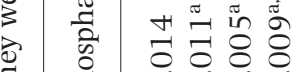

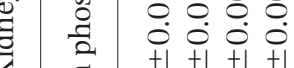

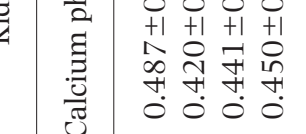

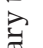

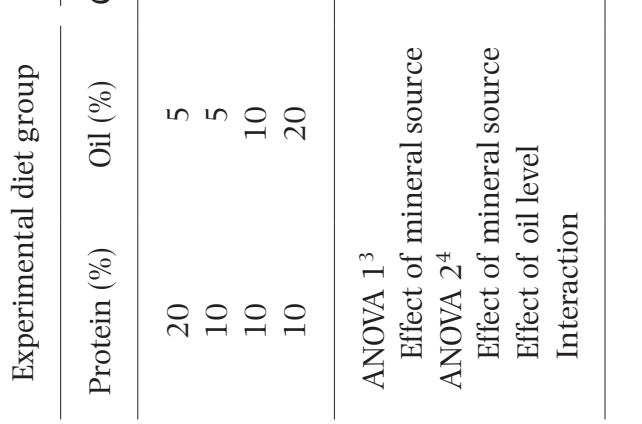

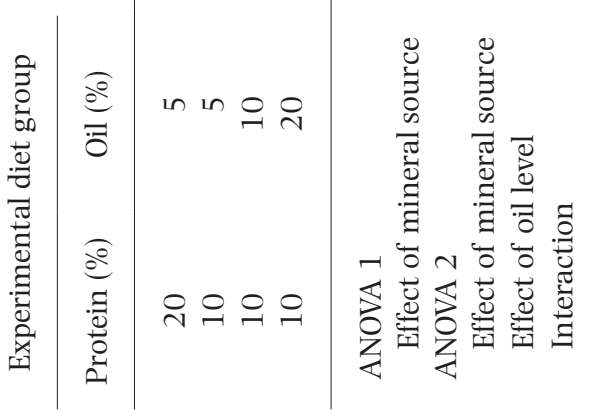

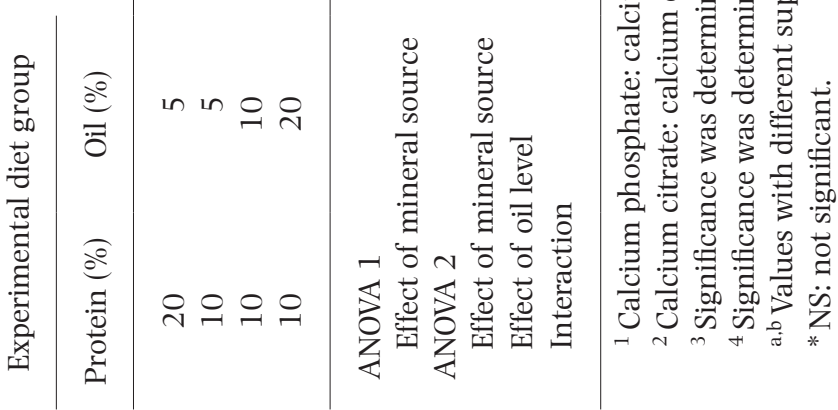

苋.

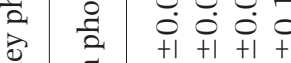

吾

ํㅏㄱ

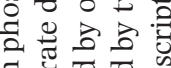

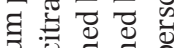

घี 쿄 है

들

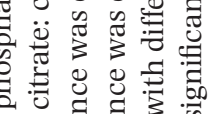

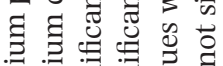

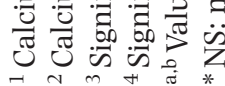


Dietary Mineral Sources and Oil Content on Kidney Calcification in Rats

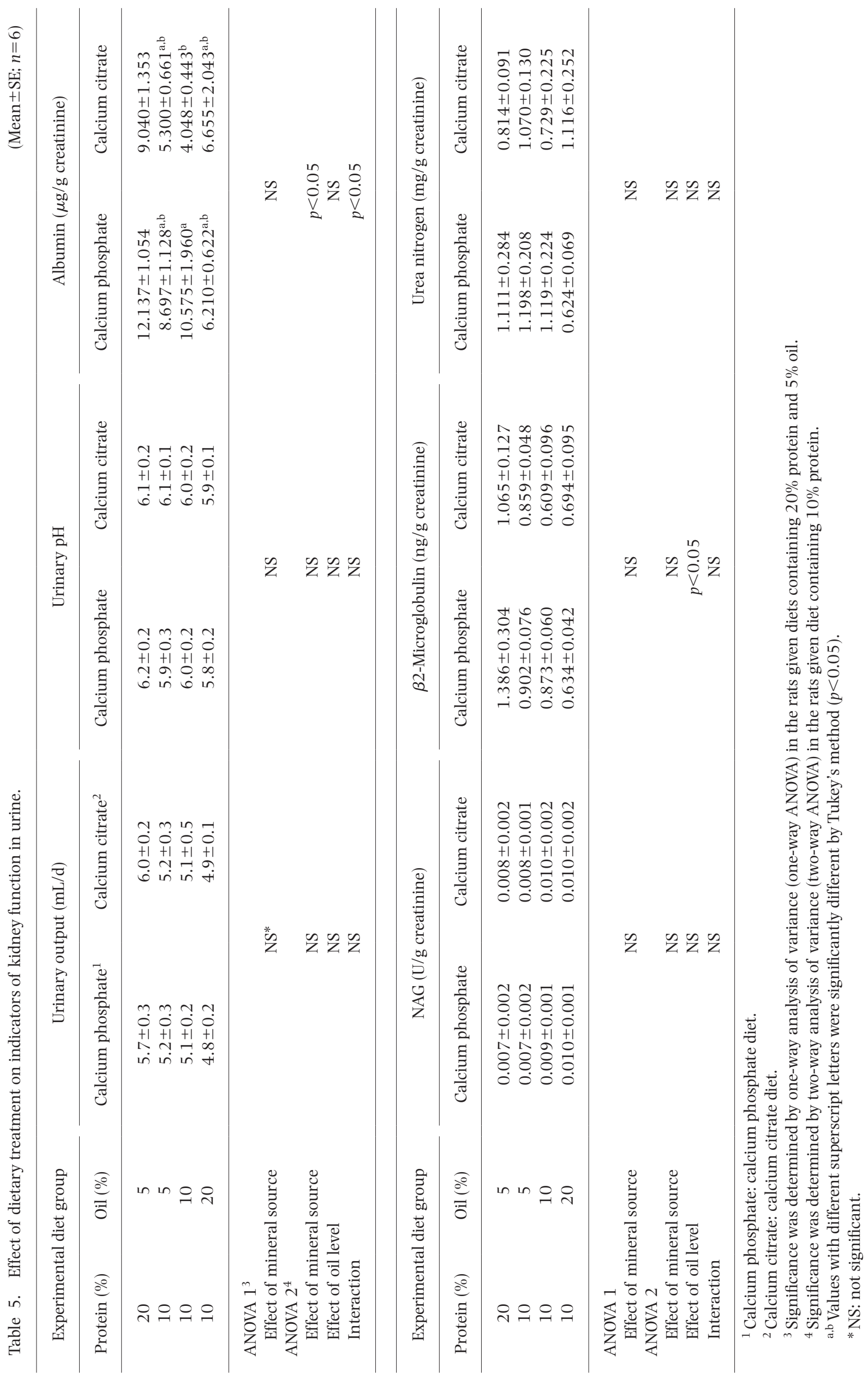



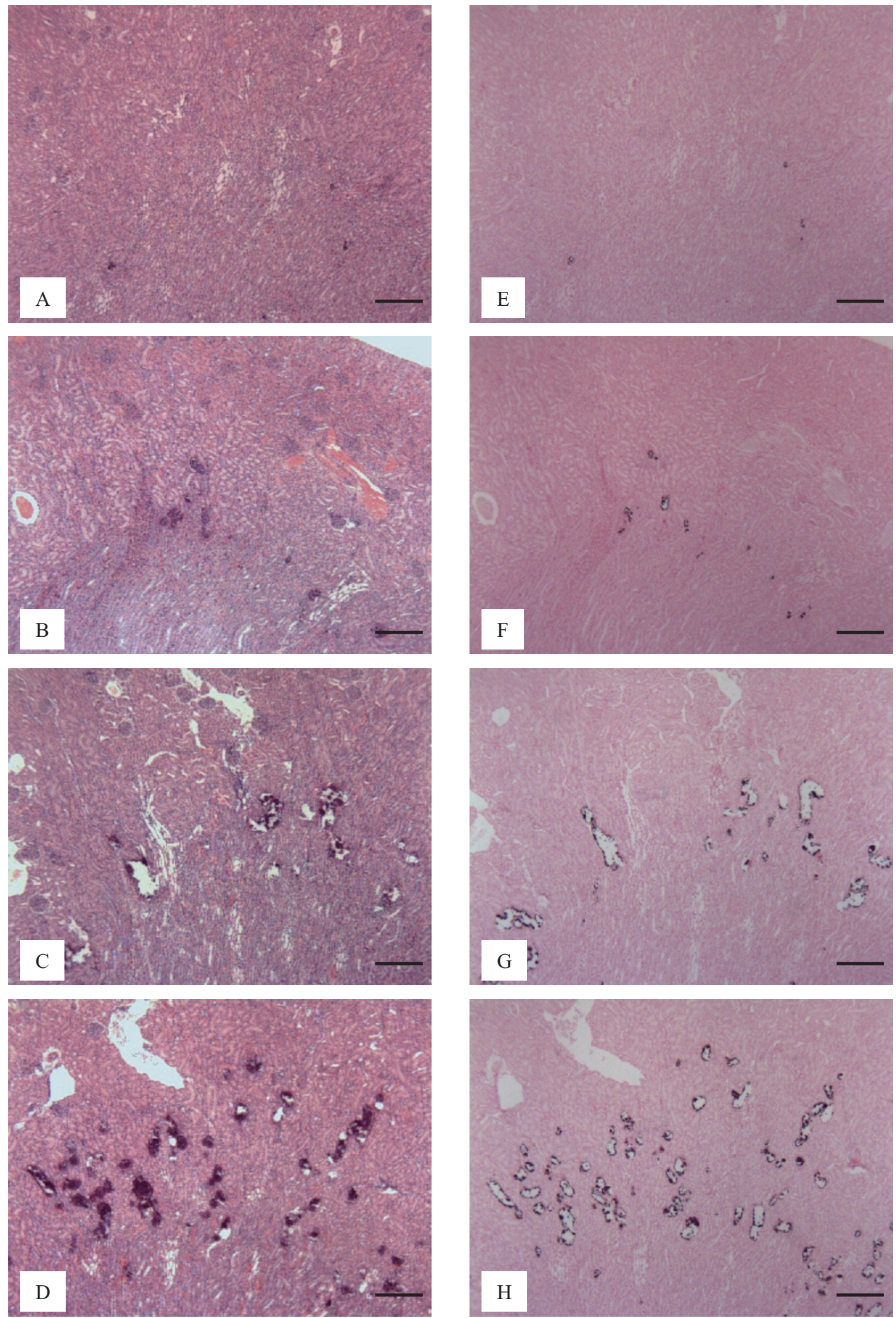

Fig. 1. Histological appearance of kidney with deposits at the corticomedullary junction in the calcium phosphate diets. (A), (B), (C), (D): H.E. stain. (E), (F), (G), (H): Von Kossa stain. (A) and (E): 20\% protein, 5\% oil diets, (B) and (F): $10 \%$ protein, 5\% oil diets, $(\mathrm{C})$ and $(\mathrm{G}):$ 10\% protein, 10\% oil diets, (D) and (H): 10\% protein, 20\% oil diets. Bars: $200 \mu \mathrm{m}$.

The experimental protocol was designed in compliance with the Guidelines for Experimental Animals of Tokyo Seiei College.

3. Balance test. Balance tests were conducted for $5 \mathrm{~d}$ (days 31 to 35 ), similar to our previous method (5).
Fractional absorption (\%) (absorption) and fractional retention (\%) (retention) were calculated using the following formulae:

Fractional absorption (\%) $=[($ intake - fecal excretion $) /$ intake $] \times 100$ 

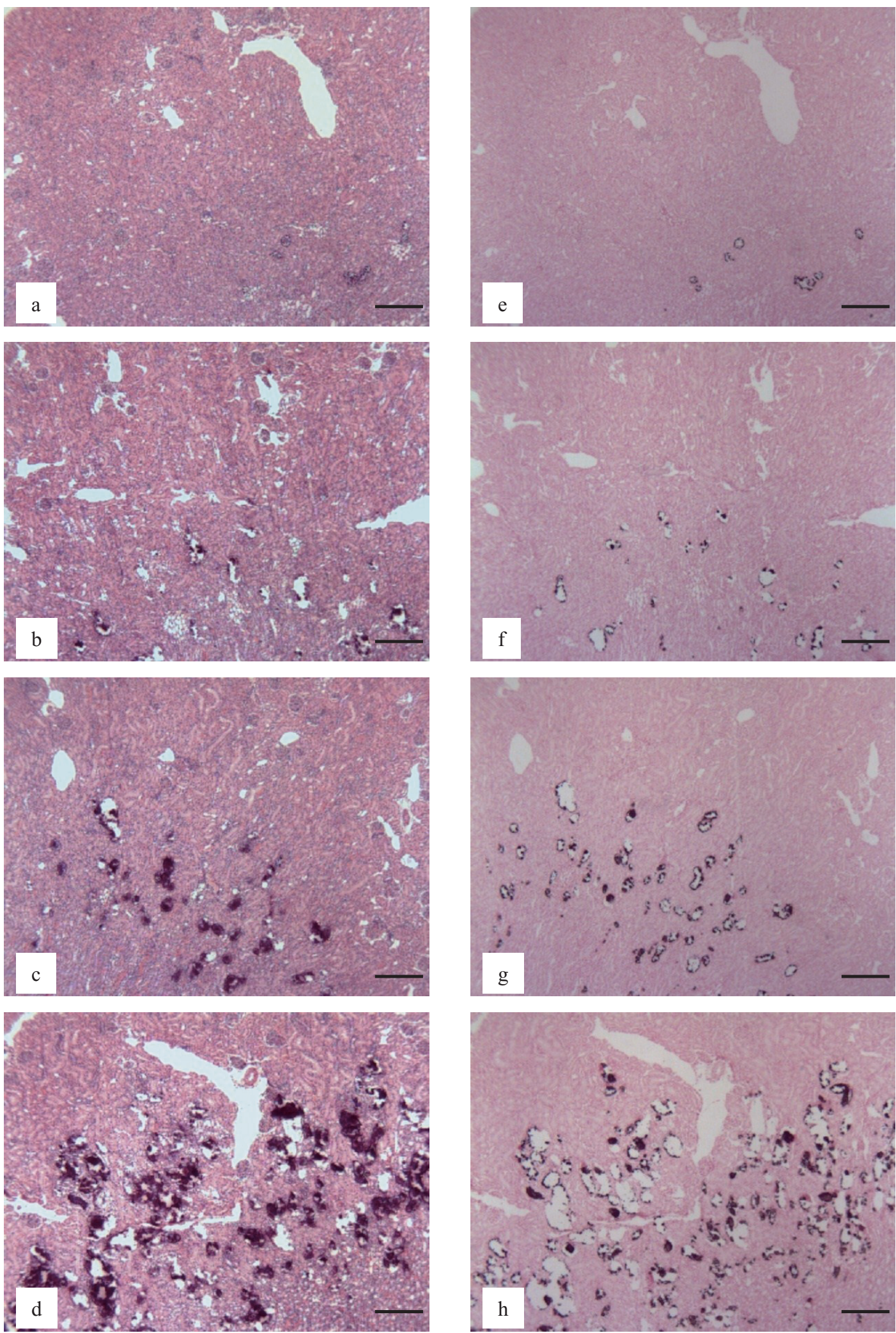

Fig. 2. Histological appearance of kidney with deposits at the corticomedullary junction in the calcium citrate diets. (a), (b), (c), (d): H.E. stain. (e), (f), (g), (h): Von Kossa stain. (a) and (e): $20 \%$ protein, $5 \%$ oil diets, (b) and (f): $10 \%$ protein, $5 \%$ oil diets, (c) and (g): 10\% protein, 10\% oil diets, (d) and (h): 10\% protein, 20\% oil diets. Bars: $200 \mu \mathrm{m}$.

Fractional retention (\%)

$=[($ intake - fecal excretion - urinary excretion $) /$ intake $] \times 100$

Fecal excretion (\%)

$=$ fecal excretion/intake $\times 100$
Urinary excretion (\%)

$$
=\text { urinary excretion/intake } \times 100
$$

4. Analytical methods.

4.1. Analyses of diets, feces, and urinary minerals: A certain amount of each sample was put in an analyti- 
cal hard test tube and was subjected to wet ashing in an aluminum dry-block bath after adding nitric acid. Then, 0.5-mol/L hydrochloric acid was added to the sample before Ca was measured using an anatomic absorption spectrophotometer (SpectrAA-20, Varian Medical Systems, Inc.).

\subsection{Biochemical examination of urine:}

(i) $\mathrm{pH}$ : Fresh urine was obtained between 10:00 and 12:00 h on day 38 and the $\mathrm{pH}$ was immediately measured using a $\mathrm{pH}$ meter (HORIBA twin $\mathrm{pH} 9$ ).

(ii) Biochemical examination: Urine samples collected for $24 \mathrm{~h}$, between 10:00 am on day 36 and 10:00 am the next morning, were subjected to biochemical examination. Kidney function was estimated using the following measurements in urine: albumin and $\beta 2$-microalbumin, determined by EIA (Panapharm Laboratories, Inc.), $N$-acetyl- $\beta$-D-glucosaminidase (NAG) activity by NAG Test Shionogi (Shionogi \& Co., Ltd.), urea nitrogen using the urease indophenol method (Wako Pure Chemical Industries, Ltd.), and creatinine using the Jaffe method (Wako Pure Chemical Industries, Ltd.). Raw measurements were corrected for $1 \mathrm{~g}$ of creatinine voided in the urine.

4.3. Kidney samples: After wet weights of the kidneys were measured, the right kidneys were subjected to mineral analysis after conventional wet ashing, as mentioned above (5), while the left kidneys were fixed with $10 \%$ neutral formalin phosphate buffer and then embedded in paraffin wax to prepare sections following the conventional method (4). The sections were stained with hematoxylin-eosin (HE) and Von Kossa for pathological observation.

5. Statistical analysis. There were 3 factors in this study: mineral source ( $\mathrm{P}$ or $\mathrm{C}$ diet), dietary protein content $(10$ or $20 \%)$ and dietary oil content $(5,10$, or $20 \%$ ). However, we did not adopt 3-way ANOVA for the statistical analysis because the oil content was set at $5 \%$ in the $20 \%$ protein diets. Thus we analyzed the data as 2 experiments; the effect of mineral source ( $\mathrm{P}$ or $\mathrm{C}$ diet) in rats given diets containing $20 \%$ protein and 5\% oil, and the effects of dietary oil content $(5,10$, or $20 \%)$ and mineral source ( $\mathrm{P}$ or $\mathrm{C}$ diet) in rats given diets containing $10 \%$ protein.

Statistical analysis was mainly conducted using ANOVA. We performed a one-way ANOVA (ANOVA1) on mineral source ( $\mathrm{P}$ or $\mathrm{C}$ diet) in rats given diets containing 20\% protein and 5\% oil. Differences between dietary oil content $(5,10$, or $20 \%)$ and mineral source (P or $\mathrm{C}$ diet), in rats given diets containing 10\% protein, were examined using a two-way ANOVA (ANOVA2).

A post hoc test was performed using Tukey's method for rats given diets containing $10 \%$ protein. Statistical significance was set at $p<0.05$ in every test. Statistical analysis was performed using Excel Statistics 2008 (Social Survey Research Information Co., Ltd.).

\section{RESULTS}

\section{Food intake and body weight gain}

Table 2 shows food intake and body weight gain in rats during the experimental period.
ANOVA1 showed that the mineral source had no significant effect on food intake or body weight gain.

ANOVA2 revealed that dietary oil content had significant effects on food intake and body weight gain. Multiple comparisons showed that an increase in the dietary oil content reduced food intake but increased body weight. The mineral source had no significant effect on food intake or body weight gain.

\section{Ca balance}

Results of the calcium balance test are shown in Table 3.

ANOVA1 showed that urinary Ca excretion was affected by the mineral source.

ANOVA2 revealed that the dietary oil content influenced Ca intake and urinary Ca excretion. Ca intake was increased in rats from the $\mathrm{P}$ diets group compared with $\mathrm{C}$ diets group, suggesting mineral sources influenced $\mathrm{Ca}$ intake. However, there was no difference in absorption or urinary excretion of Ca between the two diet groups.

3. Kidney weight and kidney mineral concentrations

Table 4 lists the kidney weight and kidney mineral concentrations.

ANOVA1 revealed that the mineral source did not affect these parameters except for kidney weight.

ANOVA2 revealed that the mineral content significantly increased as the dietary oil content was increased: Ca contents were $0.302 \pm 0.102,1.293 \pm 0.306$, and $2.117 \pm 0.533 \mathrm{mg}$ in the 5,10 , and $20 \%$ oil diet groups of the $\mathrm{P}$ diets group, respectively and 1.104 \pm 0.488 , $2.718 \pm 0.629$, and $7.217 \pm 2.191 \mathrm{mg}$ in the 5,10 , and $20 \%$ oil groups of the $\mathrm{C}$ diets group, respectively. In summary, kidney $\mathrm{Ca}, \mathrm{P}$, and magnesium $(\mathrm{Mg})$ contents per $1 \mathrm{~g}$ kidney were significantly increased in proportion to the dietary oil content.

Mineral source influenced kidney weight per se or per $100 \mathrm{~g}$ body weight. Ratios of the Ca contents per $1 \mathrm{~g}$ kidney in the $\mathrm{C}$ diets group compared to those in the $\mathrm{P}$ diets group were 3.7, 2.1, and 3.4-fold in the 5, 10, 20\% oil diet groups, respectively, indicating distinctive effects of the mineral source.

\section{Indicators of kidney function}

Table 5 lists the urinary biochemical markers of kidney function.

ANOVA1 revealed that urinary $\mathrm{pH}$, albumin, NAG activity, $\beta 2$-microglobulin level, and the urea nitrogen level were not significantly affected by the mineral source in the diet.

ANOVA2 revealed that the dietary oil content influenced $\beta 2$-microglobulin and interaction of mineral source and oil level influenced albumin.

5. Histological findings of the kidney and kidney calcification

Histological findings are presented in Fig. 1 and 2, while calcified lesions are depicted in Table 6. When fed the $20 \%$ protein diet, rats in the $\mathrm{P}$ diets group and $\mathrm{C}$ diets group showed no difference in their degree of calcification, which was minimal.

When fed the $10 \%$ protein diet, rats in the $\mathrm{C}$ and $\mathrm{P}$ diets groups showed more calcification in proportion to the amount of oil intake. The kidneys of rats in the $\mathrm{C}$ diets group were markedly advanced in calcification 
compared to rats in the $\mathrm{P}$ diets group. Histological examination of the kidneys disclosed calcification at the corticomedullary junction.

\section{DISCUSSION}

We have been continuing animal experiments using AIN-76 in an attempt to systematically prove that this diet provokes kidney calcification, not only via its specific $\mathrm{Ca} / \mathrm{P}$ molar ratio but also via effects of other nutrients, as we reported previously (1-5). In addition, the observation of such calcified lesions may make it possible to clarify $\mathrm{Ca}$ utilization in relation to other nutrients in rats.

As described in "Experimental Methods," this experiment was performed to observe the effects of mineral sources without alteration to the original dietary $\mathrm{Ca} / \mathrm{P}$ molar ratio.

The $20 \%$ protein and $5 \%$ oil diet based on AIN-76 has been used as a control or standard diet in many experimental studies.

Matsuzaki et al. showed that a high $\mathrm{P}$ diet, based on AIN-76, affected kidney calcification (12). Their control group, fed a $20 \%$ protein diet, showed the same level of kidney $\mathrm{Ca}$ and $\mathrm{P}$ contents as in our present study. Chonan et al., who observed the effects of a high $\mathrm{P}$ and Ca diet, based on AIN-76, in the kidney (13), also reported the kidney $\mathrm{Ca}, \mathrm{P}$, and $\mathrm{Mg}$ contents in their control group to be consistent with our results.

Kidney $\mathrm{Ca}, \mathrm{P}$, and $\mathrm{Mg}$ contents were not significantly different between the $\mathrm{P}$ and $\mathrm{C}$ diet groups in rats fed a $20 \%$ protein and $5 \%$ oil diet.

There was no significant difference in Ca absorption or $\mathrm{Ca}$ retention between the $\mathrm{P}$ and $\mathrm{C}$ diet groups, although $\mathrm{Ca}$ intake and urinary $\mathrm{Ca}$ excretion were significantly different.

Kusano et al. reported that urinary albumin excretion was increased by protein intake in rats $(14,15)$. Matsuzaki and Nakamura showed that urinary albumin excretion was increased by high-P diets and Mg-deficient diets in rats (16).

Although urinary albumin excretion is an indicator of kidney function $(17,18)$, there were no significant differences in urinary indicators or pathological status of the kidney due to differing mineral sources in rats given diets containing $20 \%$ protein.

Consequently, it is assumed that kidney calcification is not influenced by mineral sources in a $20 \%$ protein, $5 \%$ oil diet as long as the $\mathrm{Ca} / \mathrm{P}$ molar ratio remains practically the same.

However, in the $10 \%$ protein diet groups, an increase in oil intake greatly changed the kidney $\mathrm{Ca}, \mathrm{P}$, and $\mathrm{Mg}$ contents, irrespective of mineral sources. Our previous study showed that in the $\mathrm{P}$ diets group, kidney Ca content increased in parallel with an increase in oil intake in the $10 \%$ protein diet group (5). This is consistent with our present results.

However, when the $\mathrm{P}$ diets group and $\mathrm{C}$ diets group were compared, there were significant differences in kidney $\mathrm{Ca}, \mathrm{P}$, and $\mathrm{Mg}$ contents between the groups, regardless of oil intake. The two diet groups differed in 
potassium and dietary citric acid levels due to different mineral sources.

Many papers researching citrate in relation to kidney and urinary calculus have been published. According to Preminger et al., administration of potassium citrate to patients with kidney stones alleviated stone formation with an increase in urinary $\mathrm{pH}$, as well as potassium excretion (19). Iguchi et al. reported a positive correlation between urinary $\mathrm{pH}$ and urinary citric acid excretion in humans ingesting high levels of protein (20). It was reported by Katoh, that rats excreted a larger amount of citric acid and $\mathrm{Ca}$ in urine, with a lower $\mathrm{pH}$, when fed an increased amount of protein (21). Occurrence of human kidney stones are suppressed through alkalinizing urine with citrate (sodium salt and/or potassium salt) administration if urine is acidified $(22,23)$.

In our present study, the mineral source did not affect urinary $\mathrm{pH}$, and there were no significant $\mathrm{pH}$ changes caused by oil intake in the $10 \%$ protein diets. In addition, urinary $\mathrm{pH}$ was not affected by changes in citric acid intake from the $\mathrm{P}$ or $\mathrm{C}$ diet, at either protein intake level.

This result showed that although citric acid intake was higher in the $\mathrm{C}$ diets group compared with the $\mathrm{P}$ diet group, intake levels did not effect kidney calcification in low-protein and high-oil diets. In addition, urinary Ca excretion was increased in the $\mathrm{C}$ diet group compared with the $\mathrm{P}$ diet group but there was no difference in urinary $\mathrm{pH}$ in either group at 20\% protein and 5\% oil levels. The results suggest citric acid intake level did not effect kidney calcification in the present study.

Matsuzaki et al. reported the effects of a high-P diet, based on AIN-76, on kidney calcification (12). They fortified the diet with tripolyphosphate. Chonan et al. also prepared a high-P and -Ca diet, based on AIN-76, to investigate its effects on the kidney. They enriched the diet with potassium phosphate (13). Matsuzaki et al. also reported on the differential effects of various doses and sources of phosphates on kidney Ca content, calcification, and function. They used sodium dihydrogen phosphate, potassium dihydrogen phosphate, sodium tripolyphosphate, and potassium tripolyphosphate (24). These experiments have shown that phosphorus plays a key role in kidney calcification. It should, however, be appreciated that simultaneously increased potassium and sodium intake, which occurs with such $\mathrm{P}$ sources mentioned above, has never been correlated with kidney calcification.

Hypertension studies, in relation to mineral intake, showed that an increase in urinary sodium excretion was reported to be associated with an increase in urinary Ca excretion $(25,26)$. It is also known that urinary sodium excretion antagonizes urinary potassium excretion $(27,28)$. It was reported that potassium intake influenced urinary Ca excretion $(29,30)$. Consequently, it is necessary to explore how calcium, sodium, and potassium output in urine influences kidney calcification. In this study, it was assumed that an increase in oil intake and potassium intake affected kidney calcification in the $10 \%$ protein diet group. We intend to clarify the relationship between potassium intake and kidney calcification using our new mineral mixture to produce different $\mathrm{Ca} / \mathrm{P}$ molar ratios.

Histological examination of the kidney disclosed that Ca deposits increased in number parallel to kidney Ca content, in accordance with reports by Ritskes-Hoitinga et al. (11), Matsuzaki et al. (12), and Chonan et al. (13). These pathological features did not greatly differ from those of our previous reports. Furthermore, Matsuzaki et al. $(12,31)$ made chronological observations of the kidney until it was calcified from a high $\mathrm{P}$ diet intake in rats. It was found that there was inter-individual variation in time until the occurrence of kidney calcification, even if rats were fed the same diet.

Matsuzaki et al. also reported that kidney calcification occurred in all rats fed a high-P diet over $5 \mathrm{wk}$; however, there was no significant difference in the kidney Ca or $\mathrm{P}$ contents in rats fed a high-P diet over $2 \mathrm{wk}$ or $5 \mathrm{wk}$.

In this study, although there was inter-individual variation in the degree of kidney calcification in the $\mathrm{C}$ and $\mathrm{P}$ diet groups there was also intra-group variation in urinary albumin and $\beta 2$-microalbumin levels in kidney. We suggest long-term feeding may eliminate the inter-individual variation.

Recently, a protein implicated in kidney calcification has been identified $(32,33)$.

We intend to extend our pathological study of kidney calcification on the basis of this finding.

\section{CONCLUSION}

Factors affecting kidney calcification were not only $\mathrm{Ca} / \mathrm{P}$ molar ratios in the diets, but also other nutrients in the diet, based on the AIN-76 diet. However, the degree of kidney calcification cannot be explained by nutrient intake levels alone.

We intend to clarify the factors affecting kidney calcification using our new mineral mixture to produce different $\mathrm{Ca} / \mathrm{P}$ molar ratios.

\section{There is no conflict of interest in this study.}

\section{REFERENCES}

1) Azami S, Hiratsuka S, Kitano T, Esashi T. 1989. Effects of dietary casein and soy protein isolate on calcium, phosphorus and magnesium balance in female rats. Japanese Journal of Nutrition and Dietetics (Jpn J Nutr) 47: 103112 (in Japanese).

2) Azami S, Hiratsuka S, Kitano T, Esashi T. 1994. Effects of dietary protein levels on kidney and urinary calcium in female rats. Nippon Eiyo Shokuryo Gakkaishi (J Jpn Soc Nutr Food Sci) 47: 117-122 (in Japanese).

3) Azami S, Hiratsuka S, Kitano T, Esashi T. 1990. Effects of dietary casein and soy protein isolate on calcium, phosphorous and magnesium balance in multiparous rats. Nippon Eiyo Shokuryo Gakkaishi (J Jpn Soc Nutr Food Sci) 43: 427-435 (in Japanese).

4) Kitano T, Futatsuka M, Otsuka Y, Esashi T, Hiratsuka S, Azami S. 1989. Effect of protein, calcium and phosphorus intake on kidney in multiparous rats. Nippon Eiyo Shokuryo Gakkaishi (J Jpn Soc Nutr Food Sci) 42: 235-243 (in Japanese).

5) Ohtsuka S, Kitano T, Maeda Y, Azami S. 2006. Effect of 
the protein and oil contents on calcium utilization in the Diets of female fischer rats that were fed by three different feeding methods. J Nutr Sci Vitaminol 52: 316-326.

6) American Institute of Nutrition, Ad Hoc Committee on Standards for Nutritional Studies. 1977. Report of the American Institute of Nutrition Ad Hoc Committee on Standards for Nutritional Studies. J Nutr 107: 1340-1348.

7) Reeves PG, Nielsen FH, Fahey GC Jr. 1993. AIN-93 purified diets for laboratory rodents: Final report of the American Institute of Nutrition Ad Hoc Writing Committee on the Reformulation of the AIN-76A Rodent diet. J Nutr 123: 1939-1951.

8) Kasaoka S, Kitano T, Hanai M, Futatsuka M, Esashi T. 1988. Effect of dietary magnesium level on nephrocalcinosis and growth in rats. J Nutr Sci Vitaminol 44: 503-514.

9) Kikuchi T, Matsuzaki H, Sato S, Kajita Y, Chiba H, Tsuchiya H, Masuyama R, Uehara M, Suzuki K, Goto S. 1988. Diminished kidney function and nephrocalcinosis in rats fed a magnesium-deficient diet. J Nutr Sci Vitaminol 44: 515-523.

10) Kitano T, Maeda Y, Ohtsuka-Hiratsuka S, Azami S, Esashi T. 1999. Effects of meal feeding pattern on magnesium balance in rats. Journal of Japanese Society for Magnesium Research (JJSMgR) 18: 1-10 (in Japanese).

11) Ritskes-Hoitinga J, Lemmens AG, Danse LHJC, Beynen AC. 1989. Phosphors-Induced nephrocalcinosis and kidney function in female rats. J Nutr 119: 1423-1431.

12) Matsuzaki H, Uehara M, Suzuki K, Liu Q-L, Sato S, Kanke Y, Goto S. 1997. High phoshorus diet rapidly induces nephrocalcinosis and proximal tubular injury in rats. $J$ Nutr Sci Vitaminol 43: 627-641.

13) Chonan O, Takahashi R, Kado S, Nagata Y, Kimura H, Uchida K, Watanuki M. 1996. Effects of calcium gluconate on the utilization of magnesium and the nephrocalcinosis in rats fed excess dietary phosphorus and calcium. J Nutr Sci Vitaminol 42: 313-323.

14) Kusano K, Segawa H, Ohnishi R, Fukushima N, Miyamoto K. 2008. Role of low protein and low phoshorous diet in the progression of chronic kidney disease in uremic rats. J Nutr Sci Vitaminol 54: 237-243.

15) Funaba M, Yano H, Kawashimai R. 1989. Effects of high protein diet and sodium bicarbonate supplementation on calcium metabolism in rats. J Nutr Sci Vitaminol 35: 495-503.

16) Matsuzaki H, Nakamura K. 2000. Effects of the dietary phosphorus level and form of phosphate salts on the kidney mineral concentration, kidney function and mineral balance in female rats. Japanese Journal of Nutrition and Dietetics (Jpn J Nutr) 58: 253-259 (in Japanese).

17) Van Camp I, Ritskes-Hoitinga J, Lemmens AG, Beynen AC. 1990. Diet-induced nephrocalcinosis and urinary excretion of albumin in female rats. Lab Anim 24: 137-141.

18) Kikuchi T, Matsuzaki H, Sato S, Kajita Y, Chiba H, Tsuchiya H, Masuyama R, Uehara M, Suzuki K, Goto S. 1998. Diminished kidney function and nephrocalcinosis in rats fed a magnesium-deficient diet. J Nutr Sci Vitaminol 44: 515-523.
19) Preminger GM, Sakhaee K, Skurla C, Pak CY. 1985. Prevention of recurrent calcium stone formation with potassium citrate therapy in patients with distal renal tubular acidosis. J Urol 134: 20-23.

20) Iguchi M, Esa A, Nagai N, Takada M, Kataoka K, Katoh Y, Kohri K , Kurita T. 1985. Urinary citrate excretion in renal stone disease. Nippon Hinyokika Gakkaishi (Jpn J Urol) 76: 1429-1438 (in Japanese).

21) Katoh K. 1989. Influence of dietary animal protein on renal stone disease. Nippon Hinyokika Gakkaishi (Jpn J Urol) 80: 823-831 (in Japanese).

22) Pak CYC, Fuller C, Sakhaee K, Preminger GM, Britton F. 1985. Long-term treatment of calcium nephrolithiasis with potassium citrate. J Urol 134: 11-19.

23) The Japanese Urological Association, Japanese Endourology.ESWL, Japan Society on Urolithiasis Research. 2002. Clinical Practice Guidelines, Urolithiasis, p 64-83. Kaneharashuppan Publishing, Tokyo.

24) Matsuzaki H, Kikuchi T, Kajita Y, Masuyama R, Uehara M, Goto S, Suzuki K. 1999. Comparison of various phosphate salts as the dietary phosphorus source on nephrocalcinosis and kidney function in rats. J Nutr Sci Vitaminol 45: 595-608. Kenpakusha, Tokyo.

25) Bowman BA, Russell RM (ed). 2007. Present Knowledge in Nutrition 9th ed, p 373-383.

26) Weaver CM, Proulx WR, Heaney RP. 1999. Choices for achieving dietary calcium within a vegetarian diet. Am J Clin Nutr 70: 543S-548S.

27) Bowman BA, Russell RM (ed). 2007. Present Knowledge in Nutrition 9th ed, p 408-420. Kenpakusha, Tokyo.

28) Cordain L, Eaton SB, Sebastian A, Mann N, Lindeberg S, Watkins BA, O'Keefe JH, Brand-Miller JB. 2005. Origins and evolution of the Western diet: health implications for the 21st century. Am J Clin Nutr 81: 341-354.

29) Tsuchida M, Date C, Nakayama T, Yamamoto T, Inoue M, Yamaguchi M, Iwaya M, Chen H, Tanaka H. 1991. Study on relationship between sodium, potassium, calcium, phosphorus, magnesium and zinc and their excretions in stool and urine or serum concentration. Japanese Journal of Nutrition and Dietetics (Jpn J Nutr) 49: 35-44 (in Japanese).

30) Kaneko K, Masaki U, Aikyo M, Yabuki K, Haga A, Matoba C, Sasaki H, Koike K. 1990. Urinary calcium and calcium balance in young women affected by high protein diet of soy protein isolate and adding sulfur-containing amino acids and/or potassium. J Nutr Sci Vitaminol 36: 105-116.

31) Matsuzaki H, Uehara M, Suzuki K, Liu Q-L, Sato S, Kanke Y, Goto S. 1997. Increased intake of phosphorus induces depression of proximal tubular function in young rats. Nutr Res 17: 831-845.

32) Kohri k, Suzuki Y, Yoshida K, Yamamoto K, Amasaki N, Yamate T, Umekawa T, Iguchi M, Sinohara H, Kurita T. 1992. Molecular cloning and sequencing of cDNA encoding urinary stone protein, which is identical to osteopontin. Biochem Biophys Res Commun 184: 859-864.

33) Kohri K. 2011. Urinary calculus and calcium metabolism. Clin Calcium 21: 11-12 (in Japanese). 